\title{
molecules
}

ISSN 1420-3049

www.mdpi.com/journal/molecules

Article

\section{Anti-Inflammatory Constituents from Bidens frondosa}

\section{Jiamei Le ${ }^{1,2, \dagger}$, Wenquan Lu ${ }^{1, \dagger}$, Xiaojuan Xiong ${ }^{2}$, Zhijun Wu ${ }^{1, *}$ and Wansheng Chen ${ }^{1, *}$}

1 Department of Pharmacy, Changzheng Hospital, Second Military Medical University, Shanghai 200003, China; E-Mails: lejiamei0923@163.com (J.L.); 1wqp@163.com (W.L.)

2 College of Chemical and Biological Engineering, Yichun University, Jiangxi 336000, China; E-Mail: ycxxxj@163.com

$\dagger$ These authors contributed equally to this work.

* Authors to whom correspondence should be addressed; E-Mails: wuzhijun999@sina.com (Z.W.); chenws126@126.com or chenwansheng@smmu.edu.cn (W.C.); Tel.: +86-21-8188-6181 (W.C.); Fax: +86-21-3310-0038 (W.C.).

Academic Editor: Derek J. McPhee

Received: 31 August 2015 / Accepted: 29 September 2015 / Published: 9 October 2015

\begin{abstract}
A new polyacetylene glucoside (3E,5E,11E)-tridecatriene-7,9-diyne-1,2,13triol-2-O- $\beta$-D-glucopyranoside (1), a new phenylpropanoid glucoside $2^{\prime}$-butoxyethylconiferin (2), and a new flavonoid glycoside 8,3',4'-trihydroxyflavone-7-O-(6"'-O-p-coumaroyl)- $\beta$-Dglucopyranoside (3), have been isolated from Bidens frondosa together with fifty-three known compounds 4-56. The structures of these compounds were established by spectroscopic methods. mainly ESIMS, 1D- and 2D-NMR spectroscopic data. and comparison with literature data. Compounds 1-34, 36, 39, 43, 47, 51, and 52 were tested for inhibition of nuclear factor kappa B $(\mathrm{NF}-\kappa \mathrm{B})$ in 293-NF- $\mathrm{B}$-luciferase report cell line induced by lipopolysaccharide (LPS), and compounds 1, 2, 3, 9, 15, 21, 24 and 51 were tested for the production of TNF- $\alpha$, IL-1 $\beta$, IL-6, IL-10 in RAW 264.7 macrophages induced by LPS. In conclusion, the isolated compounds 1, 2, 3, 9, 15, 21, 24 and 51 exhibited significant activity in anti-inflammatory activity assays.
\end{abstract}

Keywords: Bidens frondosa; polyacetylene glucoside; phenylpropanoid glucoside; flavonoid glycoside; anti-inflammatory activity 


\section{Introduction}

Bidens frondosa (L.) is an annual herbaceous plant growing widely on nutrient-rich mudsoils or muddy sandsoils at the shores of rivers and lakes, which is one of species of genus Bidens from the family Asteraceae. It is native to North America, and now distributed throughout China. It has attracted a great deal of attention for its wide range of biological activities, such as antibacterial [1], antioxidant [2], antimalarial [3] and antidiarrheal [4]. Previous studies reported that B. frondosa contained acetylene [3], polyenic D-glucosides [5,6], chalcones and aurones [2,3,7,8], flavones and terpenes [9]. However, a literature survey reveals that there are no reports on the anti-inflammatory activity of $B$. frondos $a$, and the research on chemical constituents of $B$. frondosa is also limited. Thus we decided to isolate chemical constituents of $B$. frondosa and to investigate its anti-inflammatory activity.

As part of an ongoing search for bioactive natural products from traditional folk medicines, we have conducted a phytochemical investigation on the EtOH extract of B. frondosa. This has led to the isolation of a new polyacetylene glucoside, a new phenylpropanoid glucoside, a new flavonoid glycoside and fifty-three known compounds, identified as $(3 E, 5 E, 11 E)$-tridecatriene-7,9-diyne-1,2,13triol-2-O- $\beta$-D-glucopyranoside (1), 2'-butoxyethylconiferin (2), 8,3',4'-trihydroxyflavone-7-O-(6"'-O- $p$ coumaroyl)- $\beta$-D-glucopyranoside (3), butylconiferin (4), 2-methoxy-4-(2-propenyl)-phenyl- $\beta$-Dglucopyranoside (5), 2-methoxy-4-(2'-hydroxyethyl)-phenol-1-O- $\beta$-D-glucopyranoside (6), (1'R,2'R)guaiacyl glycerol 3'-O- $\beta$-D-glucopyranoside (7), threo-5-hydroxy-3,7-dimethoxyphenylpropane-8,9-diol (8), 3-(4-hydroxy-3-methoxyphenyl)-3-methoxypropane-1,2-diol (9), 3-(4-hydroxy-3-methoxy-phenyl)propane-1,2-diol (10), guaiacylglycerol (11), ananasate (12), $p$-hydroxyphenyl-6- $O$-trans-caffeoyl- $\beta$-Dalloside (13), 6'-O-caffeoyl- $p$-hydroxyacetophenone-4- $O$ - $\beta$-D-glucopyranoside (14), wilfordiol B (15), 4,5-di- $O$-caffeoylquinic acid 1-methyl ether (16), caffeoylcalleryanin (17), 1- $O$ - $(E)$-caffeoyl- $\beta$-Dgentiobiose (18), plantasioside (19), okanin-4'-O-(6"'-O-p-coumaroyl- $\beta$-D-glucopyranoside) (20), (-)-4'-methoxy-7-O-(6"'-acetyl)- $\beta$-D-glucopyranosyl-8,3'-dihydroxyflavanone (21), (-)-4'-methoxy-7$O$ - $\beta$-D-glucopyranosyl-8,3'-dihydroxyflavanone (22), hesperetin-7- $O-\beta$-D-glucopyranoside (23), apigenin (24), 3'-hydroxyscutellarein-7-O-(6"-O-protocatechuoyl)- $\beta$-glucopyranoside (25), quercetin3-O-glucopyranoside (26), 8,3',4'-trihydroxyflavone-7-O- $\beta$-D-glucopyranoside (27), luteolin-7-Oglucoside (28), 6-hydroxyluteolin-7-O-glucoside (29), 3"-(3-hydroxy-3-methyl-glutaroyl)-ester of 6-hydroxy-luteolin-7-O- $\beta$-D-glucopyranoside (30), luteolin-7-O-( $\beta$-D-glucopyranosyl)-2-glucopyranoside (31), (Z)-7-O- $\beta$-D-glucopyranosyl-6,7,3',4'-tetrahydroxyaurone (32), sulfuretin-6- $O$ - $\beta$-D-glucoside (33), maritimetin-6- $O$ - $\beta$-D-glucoside (34), dihydrophaseic acid (35), caffeic acid (36), isoferuloyl ethyl ester (37), protocatechuic acid (38), 1,3,5-trimethoxybenzene (39), vanillin (40), 7R,11R-phytol (41), 1-octacosanol (42), indole-3-carboxylic acid (43), $1 H$-indole-3-carboxadehyde (44), niacinamide (45), $\beta$-sitosterol (46), stigmasterol (47), hiziprafuran (48), 5-hydroxy-2-furaldehyde (49), $\alpha$-tocopherol (50), 4-hydroxy-2-furaldehyde (51), $\alpha$-tocospiro A (52), ethyl linoleate (53), methyl linolenate (54), tripalmitolein (55) and trilinolenin (56). Compounds 1-34, 36, 39, 43, 47, 51, and 52 were tested for anti-inflammatory activities, and several of the isolated compounds $(\mathbf{1}, \mathbf{2}, \mathbf{3}, \mathbf{9}, \mathbf{1 5}, \mathbf{2 1}, 24$ and 51) exhibited significant activities in anti-inflammatory activity assays. Here, we report the isolation of these compounds, structure elucidation of three new compounds and anti-inflammatory activities of compounds 1, 2, 3, 9, 15, 21, 24 and 51. 


\section{Results and Discussion}

The $80 \%$ EtOH extract of air-dried $B$. frondosa was suspended in $\mathrm{H}_{2} \mathrm{O}$ and partitioned successively with petroleum ether, EtOAc and $n-\mathrm{BuOH}$, respectively. The petroleum ether, EtOAc and $n-\mathrm{BuOH}$ fractions were then purified repeatedly by column chromatography with silica gel, Sephadex LH-20 and ODS C18 to yield compounds $\mathbf{1}-\mathbf{5 6}$.

\subsection{Structural Elucidation of Isolated Compounds}

Compound 1 was isolated as a brownish amorphous powder. The positive HR-ESIMS showed a pseudo-molecular ion at $\mathrm{m} / \mathrm{z} 403.1371[\mathrm{M}+\mathrm{Na}]^{+}$(calcd. for $\mathrm{C}_{19} \mathrm{H}_{24} \mathrm{O} 8 \mathrm{Na}, 403.1369$ ), consistent with the formula $\mathrm{C}_{19} \mathrm{H}_{24} \mathrm{O}_{8}$, indicating the presence of eight degrees of unsaturation. The IR spectrum showed absorptions due to hydroxy $\left(3362 \mathrm{~cm}^{-1}\right)$ and olefinic bond $\left(1658,1632 \mathrm{~cm}^{-1}\right)$ moieties. The ${ }^{13} \mathrm{C}-\mathrm{NMR}$ spectrum exhibited 19 carbon resonances, classified into four quaternary carbons, twelve methines including five oxygen-substituted carbons, and three oxygen-substituted methylenes. By analysis of degrees of unsaturation, four quaternary carbon signals at $\delta_{\mathrm{C}} 81.9,81.5,76.2,73.8$ were ascribed to two acetylene bonds. The signals at $\delta_{\mathrm{C}} 149.5,145.5,137.9,129.8,109.1,106.4$ were ascribed to three double bonds. The signals at $\delta_{\mathrm{C}} 102.7,77.1,76.8,74.0,70.2,61.0$ were assigned to a glucopyranosyl unit. In the ${ }^{1} \mathrm{H}-\mathrm{NMR}$ spectrum, the signals at $\delta_{\mathrm{H}} 6.81(1 \mathrm{H}, \mathrm{dd}, J=15.6,10.8 \mathrm{~Hz}), 6.48$ $(1 \mathrm{H}, \mathrm{ddd}, J=16.2,9.0,8.4 \mathrm{~Hz}), 6.41(1 \mathrm{H}, \mathrm{dd}, J=15.6,10.8 \mathrm{~Hz}), 6.00(1 \mathrm{H}, \mathrm{dd}, J=15.6,5.4 \mathrm{~Hz}), 5.88$ $(1 \mathrm{H}, \mathrm{d}, J=15.6 \mathrm{~Hz}), 5.86(1 \mathrm{H}, \mathrm{d}, J=16.2 \mathrm{~Hz})$ implied the presence of three conjugated double bonds with $E$ geometry as deduced from the coupling constants [10]. The ${ }^{1} \mathrm{H}-$ and ${ }^{13} \mathrm{C}-\mathrm{NMR}$ spectra of 1 were quite similar to those of $(2 E, 8 E, 10 E)$-tridecatriene-4,6-diyne-1,12,13-triol-1-O- $\beta$-D-glucopyranoside (1a) [11] (Figure S1). A comparison of its spectrum with 1a showed that the glucopyranosyl unit was linked at C-2 in compound 1 instead of C-1 in compound 1a. HMBC correlation from $\mathrm{H}-1^{\prime}\left(\delta_{\mathrm{H}} 4.27, \mathrm{~d}\right.$, $J=7.8 \mathrm{~Hz})$ to $\mathrm{C}-2\left(\delta_{\mathrm{C}} 79.9\right)$ confirmed the glucopyranosyl unit was linked at C-2. The configuration of $\mathrm{C}-2$ remained undetermined. Therefore, the structure of $\mathbf{1}$ was elucidated as $(3 E, 5 E, 11 E)$-tridecatriene7,9-diyne-1,2,13-triol-2-O- $\beta$-D-glucopyranoside (Figure 1).

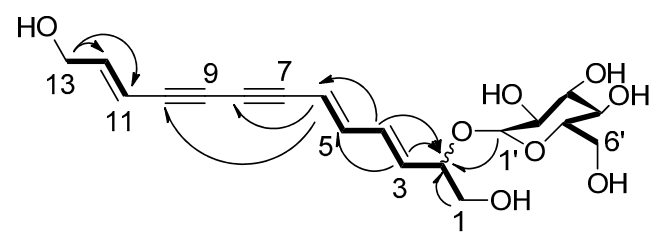

${ }^{1} \mathrm{H}-{ }^{1} \mathrm{H} \operatorname{COSY}-$
$\operatorname{HMBC}(\mathrm{H} \rightarrow \mathrm{C}) \frown$

Figure 1. Key ${ }^{1} \mathrm{H}-{ }^{1} \mathrm{H}$ COSY and $\mathrm{HMBC}(\mathrm{H} \rightarrow \mathrm{C})$ correlations of compound $\mathbf{1}$.

Compound 2 was isolated as a white amorphous powder. The negative HR-ESIMS showed a pseudo-molecular ion at $m / z 477.1917\left[\mathrm{M}+\mathrm{Cl}^{-}\right.$(calcd for $\mathrm{C}_{22} \mathrm{H}_{34} \mathrm{O} 9 \mathrm{Cl}, 477.1891$ ), consistent with the formula $\mathrm{C}_{22} \mathrm{H}_{34} \mathrm{O} 9$, indicating the presence of six degrees of unsaturation. The ${ }^{13} \mathrm{C}$-NMR spectrum exhibited 22 carbon resonances, classified into three quaternary carbons, ten methines including four oxygen-substituted carbons, seven methylenes including five oxygen-substituted carbons, one methyl group and one methoxyl group. By analysis of degrees of unsaturation, the signals at $\delta \mathrm{c} 133.3,125.9$ were ascribed to a double bond and the signals at $\delta_{\mathrm{C}} 150.9,147.8,133.4,120.9,117.9,111.4$ were 
ascribed to an aromatic ring. The DEPT spectrum showed signals at $\delta_{\mathrm{C}} 71.2,70.5$ and $72.1,32.8,20.3$, 14.2 that were ascribed to a $-O-C-1^{\prime}-C-2^{\prime}-O$ - diether chain and a terminal $-O-C-1^{\prime \prime}-C-2^{\prime \prime}-C-3^{\prime \prime}-C-4^{\prime \prime}$ chain, respectively The signals at $\delta \mathrm{C} 102.7,78.2,77.8,74.9,71.3,62.5$ were assigned to a glucopyranosyl unit. In the ${ }^{1} \mathrm{H}-\mathrm{NMR}$ spectrum, the signals at $\delta \mathrm{H} 6.54(1 \mathrm{H}, \mathrm{d}, J=15.6 \mathrm{~Hz}), 6.20(1 \mathrm{H}, \mathrm{dd}, J=15.6,6.0 \mathrm{~Hz})$ implied the presence of a conjugated double bond with $E$ geometry as deduced from the coupling constants. The signals at $\delta_{\mathrm{H}} 7.06(1 \mathrm{H}, \mathrm{d}, J=8.4 \mathrm{~Hz}), 7.03(1 \mathrm{H}, \mathrm{d}, J=1.8 \mathrm{~Hz}), 6.90(1 \mathrm{H}, \mathrm{dd}, J=8.4,1.8 \mathrm{~Hz})$ showed an $\mathrm{ABX}$ aromatic ring spin system and implied the presence of 1,3,4-trisubstituted aromatic ring [10]. The ${ }^{1} \mathrm{H}$ - and ${ }^{13} \mathrm{C}-\mathrm{NMR}$ spectra of $\mathbf{2}$ were quite similar to those of ethylconiferin (2a) [12] (Figure S1). Detailed comparison of the NMR data of $\mathbf{2}$ with $\mathbf{2 a}$ indicated that there was an additional butoxy group in compound 2. In the HMBC spectrum of 2, a correlation from $\mathrm{H}-2^{\prime}\left(\delta_{\mathrm{H}} 3.56\right)$ to the $\mathrm{C}-1$ " $\left(\delta_{\mathrm{C}} 72.1\right)$ position of the butoxy was observed, which suggested the butoxy was linked at C-2'. The structure of 2 was established on the basis of $1 \mathrm{D}$ - and 2D-NMR spectra $\left({ }^{1} \mathrm{H},{ }^{13} \mathrm{C}\right.$, DEPT, COSY, HSQC and HMBC). Accordingly, the structure of compound $\mathbf{2}$ was elucidated as 2'-butoxyethylconiferin (Figure 2). In addition, we have found compound $\mathbf{2}$ was present in a crude extract before contact with butanol, which was tested by HPLC (Figure S24). From HR-ESIMS, 1D- and 2D-NMR spectroscopic data (Figure S9-S15) and the HPLC profile, we think that compound $\mathbf{2}$ is a natural chemical constituent and not an isolation artefact.
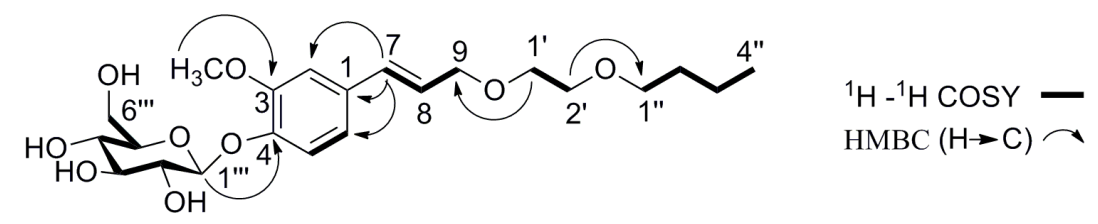

Figure 2. Key ${ }^{1} \mathrm{H}-{ }^{1} \mathrm{H}$ COSY and $\mathrm{HMBC}(\mathrm{H} \rightarrow \mathrm{C})$ correlations of compound 2.

Compound 3 was isolated as a brownish-yellow amorphous powder. The negative HR-ESIMS showed a pseudo-molecular ion at $m / z 593.1316[\mathrm{M}-\mathrm{H}]^{-}$(calcd for $\mathrm{C}_{30} \mathrm{H}_{25} \mathrm{O}_{13}, 593.1295$ ), consistent with the formula $\mathrm{C}_{30} \mathrm{H}_{26} \mathrm{O}_{13}$, indicating the presence of 18 degrees of unsaturation. The IR spectrum showed absorptions due to hydroxy $\left(3405 \mathrm{~cm}^{-1}\right)$, aromatic ring $\left(1513,1443 \mathrm{~cm}^{-1}\right)$ and olefinic bonds $\left(1688,1649 \mathrm{~cm}^{-1}\right)$. The ${ }^{13} \mathrm{C}$-NMR spectrum exhibited 30 carbon resonances, classified into twelve quaternary carbons, seventeen methines including four oxygen-substituted carbons, one oxygen-substituted methylenes. The signals at $\delta_{\mathrm{C}} 182.6,154.4,152.3,145.8,132.8,117.4,114.4,113.2,112.0$ were ascribed to a flavonoids skeleton. The signals at $\delta_{\mathrm{C}} 166.7,160.2,145.2,130.6,125.3,116.1,114.2$ were ascribed to a $p$-coumaroyl group. The signals at $\delta_{\mathrm{C}} 101.4,75.8,74.4,73.4,70.2,63.5$ were assigned to a glucopyranosyl unit. In the ${ }^{1} \mathrm{H}-\mathrm{NMR}$ spectrum, the signals at $\delta_{\mathrm{H}} 7.54(1 \mathrm{H}, \mathrm{d}, J=16.2 \mathrm{~Hz})$ and $6.39(1 \mathrm{H}, \mathrm{d}, J=16.2 \mathrm{~Hz})$ implied the presence of a conjugated double bond with $E$ geometry as deduced from the coupling constants. The signals at $\delta_{\mathrm{H}} 7.44(1 \mathrm{H}, \mathrm{d}, J=1.8 \mathrm{~Hz}), 7.33(1 \mathrm{H}, \mathrm{dd}, J=7.8$, $1.8 \mathrm{~Hz})$ and $6.85(1 \mathrm{H}, \mathrm{d}, J=7.8 \mathrm{~Hz})$ showed an aromatic ring ABX spin system and implied the presence of a 1,3,4-trisubstituted aromatic ring. The signals at $\delta_{\mathrm{H}} 7.53(2 \mathrm{H}, \mathrm{d}, J=9.0 \mathrm{~Hz})$ and 6.79 $(2 \mathrm{H}, \mathrm{d}, J=9.0 \mathrm{~Hz})$ implied the presence of a 1,4-disubstituted aromatic ring [10]. A comparison of its spectrum with that of $8,3^{\prime}, 4^{\prime}$-trihydroxyflavone-7- $O$ - $\beta$-D-glucopyranoside (27), showed that the obvious difference in 3 was an additional $p$-coumaroyl [13] (Figure S1). HMBC correlation from H-6" $\left(\delta_{\mathrm{H}} 4.44,4.21\right)$ to $\mathrm{C}-9^{\prime \prime \prime}\left(\delta_{\mathrm{C}} 166.7\right)$ suggested the $p$-coumaroyl group was linked at C-6". Accordingly, 
compound 3 was elucidated as 8,3',4'-trihydroxyflavone-7-O-(6"-O-p-coumaroyl)- $\beta$-D-glucopyranoside (Figure 3).

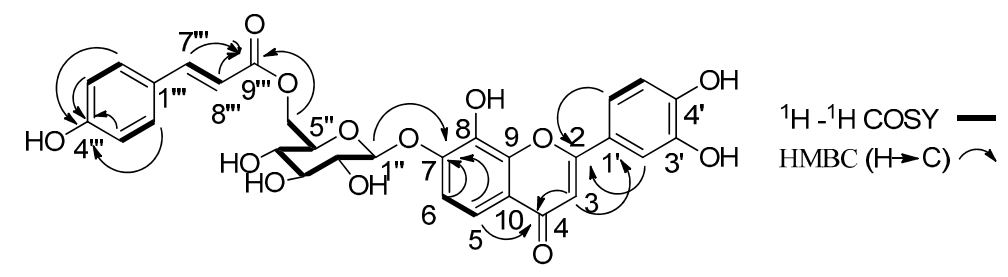

Figure 3. Key ${ }^{1} \mathrm{H}-{ }^{1} \mathrm{H}$ COSY and $\mathrm{HMBC}(\mathrm{H} \rightarrow \mathrm{C})$ correlations of compound 3.

In addition to three new glucosides 1-3, fifty-three known compounds, identified as butylconiferin (4) $[14], 2$-methoxy-4-(2-propenyl)-phenyl- $\beta$-D-glucopyranoside (5) [15], 2-methoxy-4-(2'-hydroxyethyl)-phenol-1-O- $\beta$-D-glucopyranoside (6) [16], $\left(1^{\prime} R, 2^{\prime} R\right)$-guaiacyl glycerol 3'-O- $\beta$-D-glucopyranoside (7) [17], threo-5-hydroxy-3,7-dimethoxyphenylpropane-8,9-diol (8) [18], 3-(4-hydroxy-3-methoxyphenyl)-3-methoxypropane-1,2-diol (9) [19], 3-(4-hydroxy-3-methoxyphenyl)-propane-1,2-diol (10) [20], guaiacylglycerol (11) [21], ananasate (12) [22], p-hydroxyphenyl-6-O-trans-caffeoyl- $\beta$-D-alloside (13) [23], 6'-O-caffeoyl- $p$-hydroxyacetophenone-4-O- $\beta$-D-glucopyranoside (14) [24], wilfordiol B (15) [25], 4,5-di-O-caffeoylquinic acid 1-methyl ether (16) [26], caffeoylcalleryanin (17) [27], 1-O-(E)caffeoyl- $\beta$-D-gentiobiose (18) [28], plantasioside (19) [29], okanin-4'-O-(6"-O-p-coumaroyl- $\beta$-Dglucopyranoside) (20) [8], (-)-4'-methoxy-7-O-(6"-acetyl)- $\beta$-D-glucopyranosyl-8, 3'-dihydroxy-flavanone (21), (-)-4'-methoxy-7-O- $\beta$-D-glucopyranosyl-8,3'-dihydroxyflavanone (22) [30], hesperetin-7-O- $\beta$-Dglucopyranoside (23) [31], apigenin (24) [32], 3'-hydroxyscutellarein-7-O-(6"'-O-proto-catechuoyl)- $\beta$ glucopyranoside (25) [33], quercetin-3-O-glucopyranoside (26) [34], 8,3',4'-trihydroxyflavone-7-O- $\beta$ D-glucopyranoside (27) [13], luteolin-7- $O$-glucoside (28), 6-hydroxyluteolin-7- $O$-glucoside (29) [35], 3"-(3-hydroxy-3-methylglutaroyl)-ester of 6-hydroxyluteolin-7-O- $\beta$-D-glucopyranoside (30) [36], luteolin-7-O-( $\beta$-D-glucopyranosyl)-2-glucopyranoside (31) [37], (Z)-7-O- $\beta$-D-glucopyranosyl-6,7,3',4'tetrahydroxyaurone (32) [38], sulfuretin-6- $O-\beta$-D-glucoside (33), maritimetin-6- $O-\beta$-D-glucoside (34) [39], dihydrophaseic acid (35) [40], caffeic acid (36), protocatechuic acid (38) [41], isoferuloyl ethylester (37) [42], 1,3,5-trimethoxybenzene (39) [43], vanillin (40) [44], 7R,11R-phytol (41) [45], 1-octacosanol (42) [46], indole-3-carboxylic acid (43) [47], 1H-indole-3-carboxadehyde (44) [48], niacinamide (45) [49], $\beta$-sitosterol (46) [50], stigmasterol (47) [51], hiziprafuran (48) [52], 5-hydroxy-2furaldehyde (49) [53], $\alpha$-tocopherol (50) [54], 4-hydroxy-2-furaldehyde (51) [55], $\alpha$-tocospiro A (52) [56], ethyl linoleate (53), methyl linolenate (54) [57], tripalmitolein (55) [58], trilinolenin (56) [59] were isolated from B. frondosa. These compounds were identified by spectral analysis, and we found their spectral data were consistent with spectroscopic data reported in the corresponding literature.

\subsection{Anti-Inflammatory Activity}

Compounds 1-34, 36, 39, 43, 47, 51, and 52 were evaluated for their anti-inflammatory activities in a luciferase assay (Table S1). Compared with the cell group, the luciferase activity of the LPS group was significantly enhanced, which indicated that the inflammatory cell model induced by LPS was constructed successfully. Then we have found the luciferase activity of compounds $(\mathbf{1}, \mathbf{2}, \mathbf{3}, \mathbf{9}, \mathbf{1 5}, \mathbf{2 1}$, 24 and 51) group were significantly decreased by comparing with the LPS group, which showed that 
they had significant inhibitory effect on NF- $\mathrm{B}$ activity. In addition, the luciferase activity decreased with the increase of sample concentration, which indicated that the inhibition of NF- $\mathrm{BB}$ activity was dose-dependent. In conclusion, compounds 1, 2, 3, 9, 15, 21, 24 and 51 showed significant inhibitory

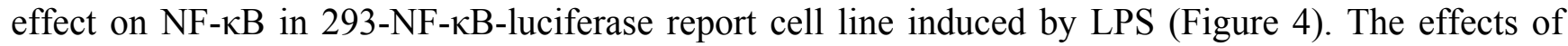
compounds $1,2,3,9,15,21,24$ and 51 on the inflammatory response were investigated further. The anti-inflammatory effects were evaluated by investigating the inhibitory activity of the compounds on the production of TNF- $\alpha$, IL-1 $\beta$, IL-6, and IL-10 in RAW 264.7 macrophages induced by LPS. For all assays, ibuprofen was used as a positive control. We have found the content of inflammatory cytokines TNF- $\alpha$, IL-6, IL-1, IL-10 of the LPS group were significantly increased by comparing with the experimental results of the Cell group, which indicated that the monocyte RAW264.7 induced by LPS was constructed successfully. Compared with the LPS group, compounds 1, 2, 3, 9, 15, 21, 24 and 51 exhibited significant inhibitory activity on the production of above inflammation factors tested in vitro at concentrations of 1,10 and $100 \mu \mathrm{g} / \mathrm{mL}$, and the inhibition activity was dose-dependent (Figures 5-8).

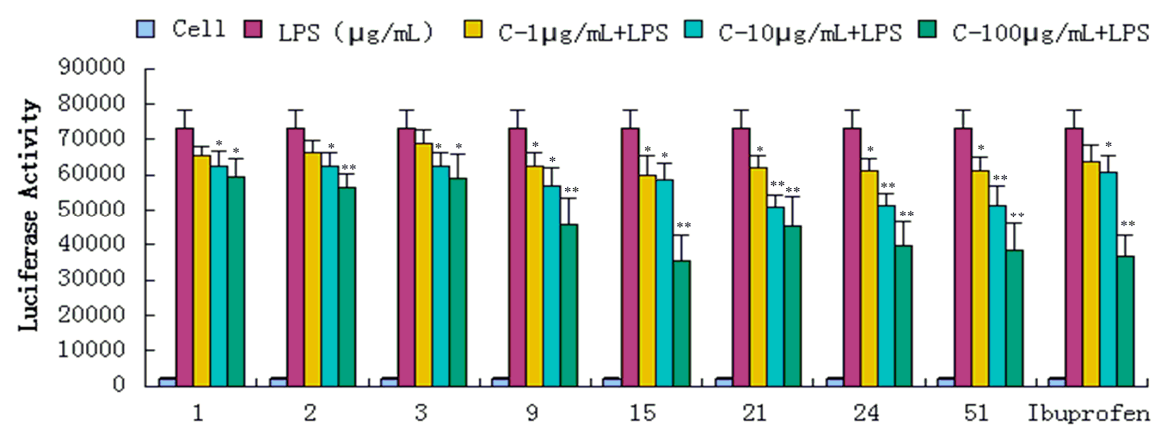

Figure 4. Inhibitory effects of compounds 1, 2, 3, 9, 15, 21, 24 and $\mathbf{5 1}(1,10,100 \mu \mathrm{g} / \mathrm{mL})$ on NF- $\mathrm{KB}$ in luciferase activity assay. Data are expressed as mean \pm S.E.M. of three independent experiments. Cell: cultures were not exposed to lipopolysaccharide (LPS); LPS: cultures were subjected to LPS; LPS + Drug: Compounds were added to the cultures during LPS; Positive control: LPS + Ibuprofen. * $p<0.05$ vs. LPS; ** $p<0.01$ vs. LPS.

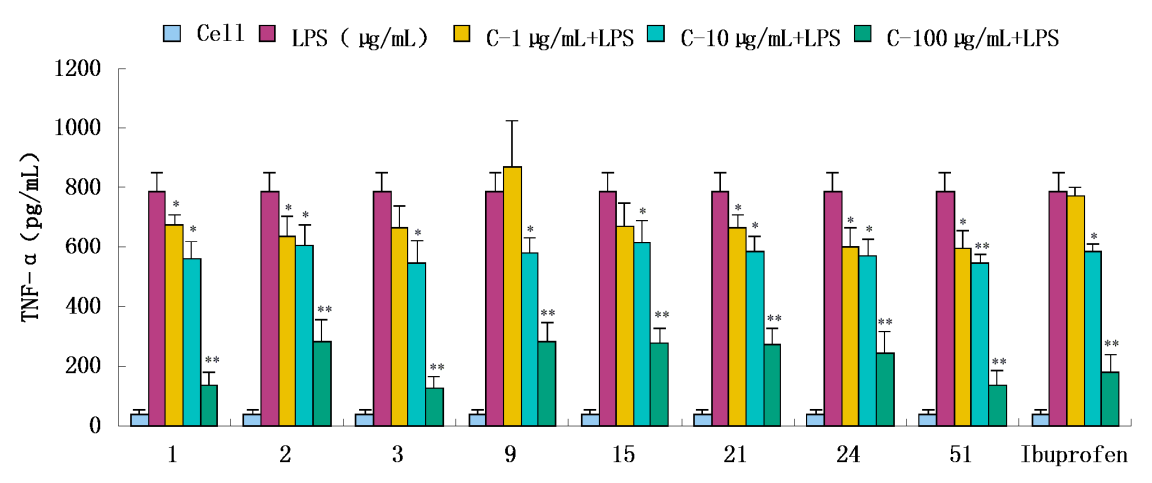

Figure 5. Inhibitory effects of compounds 1, 2, 3, 9, 15, 21, 24 and $\mathbf{5 1}(1,10,100 \mu \mathrm{g} / \mathrm{mL})$ on TNF- $\alpha$ production stimulated by LPS $(10 \mu \mathrm{g} / \mathrm{mL})$ in RAW 264.7 cells (mouse leukemic monocyte macrophage cell line). Data are expressed as mean \pm S.E.M. of three independent experiments. Cell: cultures were not exposed to lipopolysaccharide (LPS); LPS: cultures were subjected to LPS; LPS + Drug: Compounds were added to the cultures during LPS; Positive control: LPS + Ibuprofen. * $p<0.05$ vs. LPS; ** $p<0.01 v s$. LPS. 


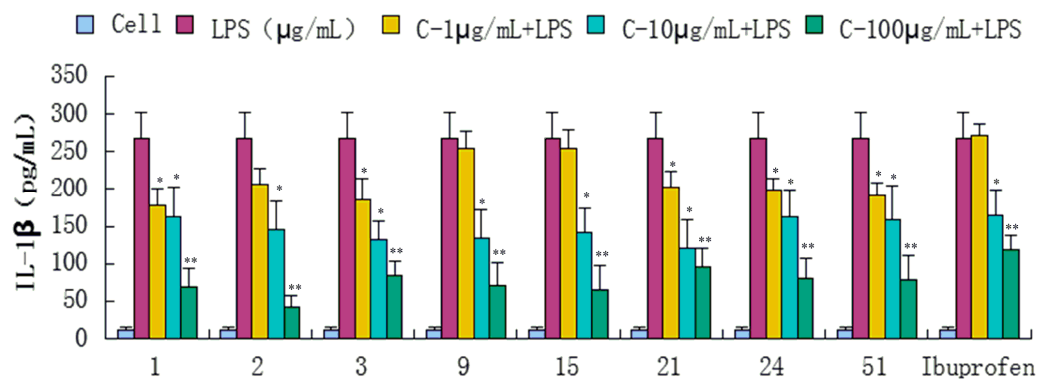

Figure 6. Inhibitory effects of compounds 1, 2, 3, 9, 15, 21, 24 and $\mathbf{5 1}(1,10,100 \mu \mathrm{g} / \mathrm{mL})$ on IL-1 $\beta$ production stimulated by LPS $(10 \mu \mathrm{g} / \mathrm{mL}$ ) in RAW 264.7 cells (mouse leukemic monocyte macrophage cell line). Data are expressed as mean \pm S.E.M. of three independent experiments. Cell: cultures were not exposed to lipopolysaccharide (LPS); LPS: cultures were subjected to LPS; LPS + Drug: Compounds were added to the cultures during LPS; Positive control: LPS + Ibuprofen. * $p<0.05$ vs. LPS; ** $p<0.01 v s$. LPS.

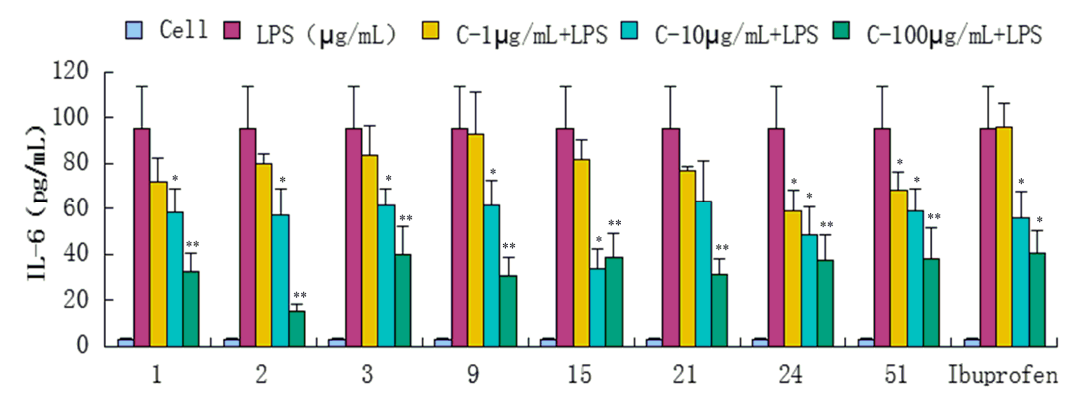

Figure 7. Inhibitory effects of compounds $\mathbf{1}, \mathbf{2}, \mathbf{3}, \mathbf{9}, \mathbf{1 5}, \mathbf{2 1}, \mathbf{2 4}$ and $\mathbf{5 1}(1,10,100 \mu \mathrm{g} / \mathrm{mL})$ on IL-6 production stimulated by LPS $(10 \mu \mathrm{g} / \mathrm{mL})$ in RAW 264.7 cells (mouse leukemic monocyte macrophage cell line). Data are expressed as mean \pm S.E.M. of three independent experiments. Cell: cultures were not exposed to lipopolysaccharide (LPS); LPS: cultures were subjected to LPS; LPS + Drug: Compounds were added to the cultures during LPS; Positive control: LPS + Ibuprofen. * $p<0.05$ vs. LPS; ** $p<0.01 v s$. LPS.

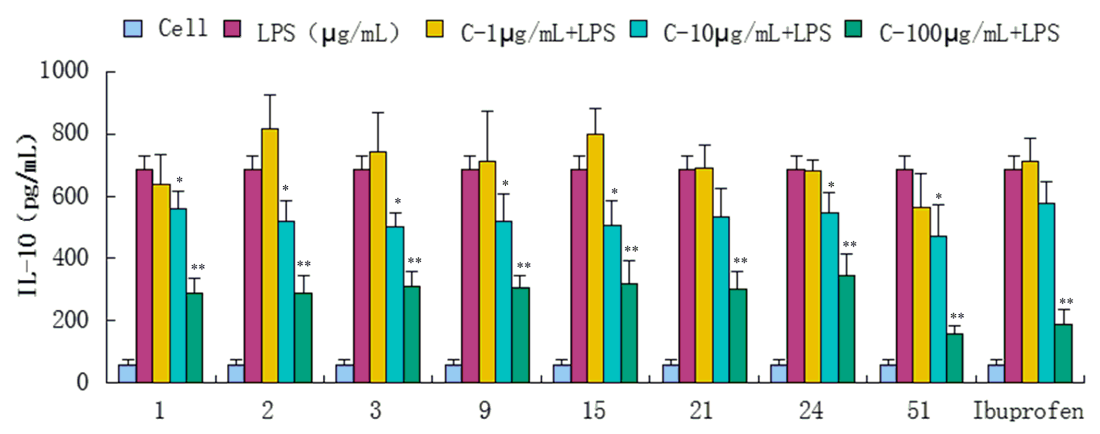

Figure 8. Inhibitory effects of compounds 1, 2, 3, 9, 15, 21, 24 and $\mathbf{5 1}(1,10,100 \mu \mathrm{g} / \mathrm{mL})$ on IL-10 production stimulated by LPS $(10 \mu \mathrm{g} / \mathrm{mL})$ in RAW 264.7 cells (mouse leukemic monocyte macrophage cell line). Data are expressed as mean \pm S.E.M. of three independent experiments. Cell: cultures were not exposed to lipopolysaccharide (LPS); LPS: cultures were subjected to LPS; LPS + Drug: Compounds were added to the cultures during LPS; Positive control: LPS + Ibuprofen. * $p<0.05$ vs. LPS; ** $p<0.01 v s$. LPS. 


\section{Experimental Section}

\subsection{General Procedures}

Optical rotations were measured on a Perkin-Elmer 341 Polarimeter (Perkin Elmer, Fremont, CA, USA). IR analyses were performed with a NEXUS 470 FT-IR spectrometer (Thermo-Nicolet, Madison, WI, USA). UV spectra were recorded on Shimadzu UV/VIS-240 recording spectrophotometer (Shimadzu, Tokyo, Japan). 1D- and 2D-NMR spectra were obtained on a Bruker Avance 600 NMR spectrometer (Bruker, Karlsruhe, Germany). HR-ESIMS were acquired on an Agilent 6220 TOF LC-MS instrument (Agilent, Santa Clara, CA, USA). Column chromatography was performed by using silica gel (100-200 and 200-300 mesh; Yantai Jiangyou Silica Gel Development Co. Ltd., Yantai, China), ODS (50 $\mu \mathrm{m}$; YMC, Wilmington, NC, USA), MCI GEL (75-150 $\mu \mathrm{m}$; Mitsubishi Chemical Corporation, Tokyo, Japan), Sephadex LH-20 (40-70 $\mu \mathrm{m}$; Pharmacia Company, Uppsala, Sweden). Semi-preparative HPLC isolation was achieved with an Agilent 1200 instrument (Agilent, Santa Clara, CA, USA) equipped with a refractive index detector (RID), using a C18 column $(250 \mathrm{~mm} \times 10 \mathrm{~mm} \times 5 \mu \mathrm{m}, \mathrm{YMC})$ and eluting with $\mathrm{MeOH}-\mathrm{H}_{2} \mathrm{O}$ at $2.0 \mathrm{~mL} / \mathrm{min}$. Precoated silica gel $\mathrm{GF}_{254}$ and $\mathrm{HF}_{254}$ plates were used for TLC, and Zones were visualized under UV light (254 nm and $365 \mathrm{~nm}$ ) or by spraying with $10 \% \mathrm{H}_{2} \mathrm{SO}_{4}-\mathrm{EtOH}$ followed by heating.

\subsection{Plant Material}

The plant of B. Frondosa was collected from Jiujiang, Jiangxi Province, during July 2013, and identified by Ceming Tan (Jiujiang Forest Herbarium, Jiangxi, China). A voucher specimen (No. 20130729) was deposited at the Department of Pharmacognosy of the Second Military Medical University.

\subsection{Extraction and Isolation}

The air-dried aerial parts of $B$. frondosa $(10 \mathrm{~kg})$ were extracted three times with $80 \% \mathrm{EtOH}$ $(100 \mathrm{~L})$ under reflux. After removal of the solvent by evaporation under vacuum, the residue was suspended in water $(10 \mathrm{~L})$ and then successively partitioned with petroleum ether, EtOAc and $n-\mathrm{BuOH}$ $(3 \times 15 \mathrm{~L})$, respectively.

The petroleum ether-soluble part (279 g) was fractionated by silica gel CC and and eluted with petroleum ether-ethyl acetate in increasing polarity $(100: 1 \rightarrow 10: 1)$ to yield six fractions (Fr.1-Fr.6). Fr.1 (42 g) was subjected to repeated silica gel CC using a step gradient of petroleum ether-EtOAc $(80: 1 \rightarrow 60: 1 \rightarrow 40: 1 \rightarrow 20: 1 \rightarrow 10: 1)$ and further purified by Sephadex LH-20 column eluted with $\mathrm{CH}_{2} \mathrm{Cl}_{2}-\mathrm{MeOH}(1: 1)$ to afford compounds 55 (85 mg). Fr.2 (50 g) was chromatographed on silica gel column and eluted with increasing polarities of petroleum ether-EtOAc $(60: 1 \rightarrow 30: 1 \rightarrow 10: 1)$ to give four subfractions (Fr.2-1-Fr.2-4). Fr.2-1 (5 g) was chromatographed on silica gel CC using a step gradient of petroleum ether-EtOAc $(50: 1 \rightarrow 20: 1 \rightarrow 10: 1)$ and finally purified by Sephadex LH-20 column eluted with $\mathrm{CH}_{2} \mathrm{Cl}_{2}-\mathrm{MeOH}(1: 1)$ to yield compound 53 (196 mg). Fr.2-2 (1.4 g) and Fr.2-4 ( $2 \mathrm{~g}$ ) was respectively separated by Sephadex LH-20 column eluted with $\mathrm{CH}_{2} \mathrm{Cl}_{2}-\mathrm{MeOH}$ (1:1) to yield compound 56 (500 mg). Fr.3 (43 g) was subjected to repeated silica gel CC using a step gradient of petroleum ether-EtOAc $(40: 1 \rightarrow 30: 1 \rightarrow 20: 1 \rightarrow 10: 1 \rightarrow 5: 1)$ and further purified by Sephadex LH-20 
column eluted with $\mathrm{CH}_{2} \mathrm{Cl}_{2}-\mathrm{MeOH}$ (1:1) to yield compounds 54 (450 mg). Fr.4 (40 g) was subjected to repeated silica gel CC using a step gradient of petroleum ether-EtOAc $(30: 1 \rightarrow 20: 1 \rightarrow 10: 1 \rightarrow 5: 1 \rightarrow 1: 1)$ and further purified by Sephadex $\mathrm{LH}-20$ column eluted with $\mathrm{CH}_{2} \mathrm{Cl}_{2}-\mathrm{MeOH}$ (1:1) to yield compounds 42 (2 mg). Fr.5 (34 g) was subjected to repeated Silica gel CC using a step gradient of petroleum ether-EtOAc $(20: 1 \rightarrow 10: 1 \rightarrow 5: 1 \rightarrow 1: 1)$ and further purified by Sephadex LH-20 column eluted with $\mathrm{CH}_{2} \mathrm{Cl}_{2}-\mathrm{MeOH}$ (1:1) to afford compounds 41 (27 mg).

The EtOAc-soluble part $(214 \mathrm{~g})$ was fractionated by silica gel $\mathrm{CC}$ eluted with $\mathrm{CH}_{2} \mathrm{Cl}_{2}-\mathrm{MeOH}$ $(50: 1 \rightarrow 4: 1)$ to give eight fractions (Fr.7-Fr.14). Fr.7 (30 g) was subjected to repeated silica gel CC eluted with $\mathrm{CH}_{2} \mathrm{Cl}_{2}-\mathrm{MeOH}(40: 1 \rightarrow 20: 1 \rightarrow 10: 1 \rightarrow 4: 1)$ and further purified by Sephadex LH-20 column eluted with $\mathrm{CH}_{2} \mathrm{Cl}_{2}-\mathrm{MeOH}$ (1:1) to afford compounds 47 (8 mg), 50 (3 mg) and $\mathbf{5 2}$ (10 mg). Fr.8 (29 g) was subjected to silica gel CC eluted with $\mathrm{CH}_{2} \mathrm{Cl}_{2}-\mathrm{MeOH}(30: 1 \rightarrow 20: 1 \rightarrow 10: 1 \rightarrow 4: 1)$, further separated by ODS CC eluted with $\mathrm{MeOH}-\mathrm{H}_{2} \mathrm{O}(40 \% \rightarrow 60 \% \rightarrow 80 \%)$ and finally purified by Sephadex LH-20 column eluted with $\mathrm{CH}_{2} \mathrm{Cl}_{2}-\mathrm{MeOH}(1: 1)$ to afford compounds 46 (100 mg), 48 (23 mg) and 49 $(19 \mathrm{mg})$. Fr.9 (23 g) was subjected to silica gel $\mathrm{CC}$ eluted with $\mathrm{CH}_{2} \mathrm{Cl}_{2}-\mathrm{MeOH}(20: 1 \rightarrow 10: 1 \rightarrow 4: 1)$, further separated by ODS CC eluted with $\mathrm{MeOH}-\mathrm{H}_{2} \mathrm{O}(40 \% \rightarrow 60 \% \rightarrow 80 \%)$ and finally purified by Sephadex LH-20 column eluted with $\mathrm{CH}_{2} \mathrm{Cl}_{2}-\mathrm{MeOH}$ (1:1) to afford compounds 43 (12 mg) and 44 (3 mg). Fr.10 (25 g) was subjected to silica gel CC eluted with $\mathrm{CH}_{2} \mathrm{Cl}_{2}-\mathrm{MeOH}(20: 1 \rightarrow 10: 1 \rightarrow 4: 1 \rightarrow 1: 1)$ and finally purified by Sephadex LH-20 column eluted with $\mathrm{CH}_{2} \mathrm{Cl}_{2}-\mathrm{MeOH}(1: 1)$ to afford compounds 45 $(10 \mathrm{mg})$ and $51(4 \mathrm{mg})$. Fr.11 (24 g) was subjected to ODS $\mathrm{CC}$ eluted with $\mathrm{MeOH}-\mathrm{H}_{2} \mathrm{O}$ $(40 \% \rightarrow 60 \% \rightarrow 80 \%)$ and finally purified by Sephadex LH-20 column eluted with $\mathrm{CH}_{2} \mathrm{Cl}_{2}-\mathrm{MeOH}(1: 1)$ to afford compound 40 (17 mg). Fr.12 (15 g) was subjected to repeated ODS CC eluted with $\mathrm{MeOH}-\mathrm{H}_{2} \mathrm{O} \quad(40 \% \rightarrow 60 \% \rightarrow 80 \%)$ and finally purified by Sephadex LH-20 column eluted with $\mathrm{CH}_{2} \mathrm{Cl}_{2}-\mathrm{MeOH}(1: 1)$ to afford compounds $35(14 \mathrm{mg})$ and $39(6 \mathrm{mg})$. Fr.13 (23 g) was subjected to ODS CC eluted with $\mathrm{MeOH}-\mathrm{H}_{2} \mathrm{O}(40 \% \rightarrow 60 \% \rightarrow 80 \%)$, further separated by silica gel CC eluted with $\mathrm{CH}_{2} \mathrm{Cl}_{2}-\mathrm{MeOH}(10: 1 \rightarrow 4: 1 \rightarrow 1: 1)$ and finally purified by Sephadex LH-20 column eluted with $\mathrm{CH}_{2} \mathrm{Cl}_{2}-\mathrm{MeOH}(1: 1)$ to afford compounds $36(74 \mathrm{mg})$ and $38(574 \mathrm{mg})$. Fr.14 (17 g) was subjected to ODS CC eluted with $\mathrm{MeOH}-\mathrm{H}_{2} \mathrm{O}(50 \% \rightarrow 70 \% \rightarrow 90 \%)$ and finally purified by Sephadex LH-20 column eluted with $\mathrm{CH}_{2} \mathrm{Cl}_{2}-\mathrm{MeOH}$ (1:1) to afford compound 37 (3 mg).

The $n$-BuOH-soluble part (325 g) was fractionated by silica gel $\mathrm{CC}$ eluted with $\mathrm{CH}_{2} \mathrm{Cl}_{2}-\mathrm{MeOH}$ $(20: 1 \rightarrow 2: 1)$ to give five fractions (Fr.15-Fr.19). Fr.15 (45 g) was subjected to ODS column with a step gradient elution $\left(50 \% \rightarrow 80 \%, \mathrm{MeOH}\right.$ in $\left.\mathrm{H}_{2} \mathrm{O}\right)$ to afford two subfractions (Fr.15-1-Fr.15-2). Fr.15-1 $(15 \mathrm{~g})$ was purified by semi-preparative $\mathrm{HPLC}\left(30 \% \mathrm{MeOH}-\mathrm{H}_{2} \mathrm{O}, 2 \mathrm{~mL} / \mathrm{min}\right)$ to give compounds 2 (2 mg), 4 (5 mg), 7 (2 mg) and $\mathbf{1 3}$ (3 mg). Fr.15-2 (20 g) was purified by Sephadex LH-20 column eluted with $\mathrm{CH}_{2} \mathrm{Cl}_{2}-\mathrm{MeOH}$ (1:1) to afford compounds 5 (595 mg), 6 (5 mg) and 28 (12 mg). Fr.16 $(60 \mathrm{~g})$ was subjected to $\mathrm{MCI}$ column with a step gradient elution $\left(50 \% \rightarrow 70 \% \rightarrow 90 \%, \mathrm{MeOH}\right.$ in $\mathrm{H}_{2} \mathrm{O}$ ) to afford three subfractions (Fr.16-1-Fr.16-3). Fr.16-1 (18 g) was purified by semi-preparative HPLC (25\% MeOH- $\left.\mathrm{H}_{2} \mathrm{O}, 2 \mathrm{~mL} / \mathrm{min}\right)$ to give compounds 8 (13 mg), 9 (2 mg) and $\mathbf{1 0}$ (4 mg). Fr.16-2 (20 g) was purified by Sephadex LH-20 column eluted with $\mathrm{CH}_{2} \mathrm{Cl}_{2}-\mathrm{MeOH}$ (1:1) to give compounds 11 (5 mg) and 12 (7 mg). Fr.16-3 (10 g) was purified by semi-preparative HPLC (40\% $\mathrm{MeOH}-\mathrm{H}_{2} \mathrm{O}$, $2 \mathrm{~mL} / \mathrm{min}$ ) to give compounds 1 (4 mg) and $\mathbf{3 3}(4 \mathrm{mg})$. Fr.17 (65 g) was subjected to ODS column with a step gradient elution $\left(5 \%-20 \%-50 \%-70 \%-90 \%, \mathrm{MeOH}\right.$ in $\left.\mathrm{H}_{2} \mathrm{O}\right)$ to afford two subfractions (Fr.17-1-Fr.17-2). Fr.17-1 (28 g) was purified by semi-preparative HPLC (25\% MeOH-H $2 \mathrm{O}, 2 \mathrm{~mL} / \mathrm{min}$ ) 
to give compounds $18(20 \mathrm{mg}), \mathbf{1 9}(20 \mathrm{mg}), \mathbf{2 1}(23 \mathrm{mg})$ and $22(7 \mathrm{mg})$. Fr.17-2 (29 g) was purified by semi-preparative HPLC (35\% MeOH- $\left.\mathrm{H}_{2} \mathrm{O}, 2 \mathrm{~mL} / \mathrm{min}\right)$ to give compounds $14(8 \mathrm{mg})$ and $20(6 \mathrm{mg})$. Fr.18 (58 g) was subjected to MCI GEL column with a step gradient elution $(5 \%-20 \%-50 \%-70 \%-90 \%$, $\mathrm{MeOH}$ in $\mathrm{H}_{2} \mathrm{O}$ ) to afford two subfractions (Fr.18-1-Fr.18-2). Fr.18-1 (21 g) was purified by semi-preparative HPLC (30\% $\left.\mathrm{MeOH}-\mathrm{H}_{2} \mathrm{O}, 2 \mathrm{~mL} / \mathrm{min}\right)$ to give compounds 23 (4 mg), 26 (5 mg), 32 $(20 \mathrm{mg})$ and $34(32 \mathrm{mg})$. Fr.18-2 (25 g) was purified by semi-preparative HPLC $\left(60 \% \mathrm{MeOH}-\mathrm{H}_{2} \mathrm{O}\right.$, $2 \mathrm{~mL} / \mathrm{min})$ to give compounds $15(57 \mathrm{mg}), 16(8 \mathrm{mg})$ and $24(3 \mathrm{mg})$. Fr.19 (58 g) was subjected to ODS column with a step gradient elution $\left(5 \%-20 \%-50 \%-70 \%-100 \%, \mathrm{MeOH}\right.$ in $\left.\mathrm{H}_{2} \mathrm{O}\right)$ to afford two subfractions (Fr.19-1-Fr.19-2). Fr.19-1 (22 g) was purified by semi-preparative HPLC (30\% MeOH- $\mathrm{H}_{2} \mathrm{O}$, $2 \mathrm{~mL} / \mathrm{min})$ to give compounds 3 (15 mg), $27(14 \mathrm{mg}), 29(5 \mathrm{mg})$ and $\mathbf{3 0}(5 \mathrm{mg})$. Fr.19-2 (21 g) was purified by semi-preparative HPLC $\left(65 \% \mathrm{MeOH}-\mathrm{H}_{2} \mathrm{O}, 2 \mathrm{~mL} / \mathrm{min}\right)$ to give compounds 17 (11 $\left.\mathrm{mg}\right), 25$ (15 $\mathrm{mg})$ and $\mathbf{3 1}(11 \mathrm{mg})$.

\subsection{Luciferase Assay}

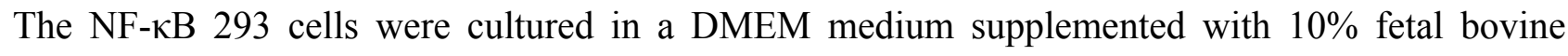
serum (FBS). The cells were pretreated with these forty compounds at concentrations of 1,10 and $100 \mu \mathrm{g} / \mathrm{mL}$ for $4 \mathrm{~h}$ and then stimulated with $10 \mu \mathrm{g} / \mathrm{mL}$ lipopolysaccharide (LPS) for $24 \mathrm{~h}$. The cells were rinsed twice with phosphate-buffered saline (PBS, $\mathrm{pH}$ 7.4) and lysed with passive lysis buffer (Promega, Madison, WI, USA). Then inhibitory effect on NF- $\kappa \mathrm{B}$ was analyzed using the luciferase assay system (Promega) according to the manufacturer's instructions [60].

\subsection{Measurement of $T N F-\alpha, I L-1 \beta, I L-6$, and $I L-10$}

The cells were cultured in serum-free medium for $8 \mathrm{~h}$ and then incubated in medium containing 1 , 10 and $100 \mu \mathrm{g} / \mathrm{mL}$ of compounds $\mathbf{1}, \mathbf{2}, \mathbf{3}, \mathbf{9}, \mathbf{1 5}, \mathbf{2 1}, \mathbf{2 4}$ and $\mathbf{5 1}$ for $2 \mathrm{~h}$. The cells were then treated with $10 \mu \mathrm{g} / \mathrm{mL}$ of LPS for $24 \mathrm{~h}$. Ibuprofen $(1,10$ and $100 \mu \mathrm{g} / \mathrm{mL})$ was used as a positive control. The supernatants of cell culture were harvested and centrifuged at $3000 \times \mathrm{g}$ at $4{ }^{\circ} \mathrm{C}$ for 2 min for the analysis of TNF- $\alpha$, IL-1 $\beta$, IL-6, and IL-10. Enzyme-linked immunosorbent assays for detecting the cytokines in the supernatants were carried out according to the instructions provided by the manufacturer. Finally, the standard provided with the kits was used to quantify each cytokine in the supernatants [61].

\subsection{Characterization of Compounds}

(3E,5E,11E)-Tridecatriene-7,9-diyne-1,2,13-triol-2-O- $\beta$-D-glucopyranoside (1): brownish amorphous powder; $[\alpha]_{\mathrm{D}}^{20}-16.25(c 0.04, \mathrm{MeOH}) ; \mathrm{UV}(\mathrm{MeOH}) \lambda_{\max }(\log \varepsilon) 339,317,298,268,253 \mathrm{~nm}$; IR $(\mathrm{KBr})$ $v_{\max } 3362,3005,2922,2852,2025,1658,1632,1467,1423,1411,1383,1075,812 \mathrm{~cm}^{-1}$; ${ }^{1} \mathrm{H}-\mathrm{NMR}$ (DMSO-d6, $600 \mathrm{MHz}): \delta 6.81(1 \mathrm{H}, \mathrm{dd}, J=15.6,10.8 \mathrm{~Hz}, \mathrm{H}-5), 6.48(1 \mathrm{H}$, ddd, $J=16.2,9.0,8.4 \mathrm{~Hz}$, H-12), 6.41 (1H, dd, $J=15.6,10.8 \mathrm{~Hz}, \mathrm{H}-4), 6.00$ (1H, dd, $J=15.6,5.4 \mathrm{~Hz}, \mathrm{H}-3), 5.88$ (1H, d, $J=15.6 \mathrm{~Hz}, \mathrm{H}-6), 5.86(1 \mathrm{H}, \mathrm{d}, J=16.2 \mathrm{~Hz}, \mathrm{H}-11), 4.27\left(1 \mathrm{H}, \mathrm{d}, J=7.8 \mathrm{~Hz}, \mathrm{H}-1^{\prime}\right), 4.22(1 \mathrm{H}, \mathrm{d}, J=4.8 \mathrm{~Hz}$, H-2), 4.05 (2H, dd, $J=4.2,2.4 \mathrm{~Hz}, \mathrm{H}-13), 3.62$ (1H, d, $\left.J=10.2 \mathrm{~Hz}, \mathrm{H}-6^{\prime} \alpha\right), 3.45$ (2H, m, H-1), 3.43 (1H, m, H-6'ß), 3.14 (1H, m, H-5'), 3.05 (1H, m, H-3'), 3.04 (1H, m, H-4'), 2.97 (1H, m, H-2'). 
${ }^{13} \mathrm{C}-\mathrm{NMR}\left(\mathrm{DMSO}-d_{6}, 150 \mathrm{MHz}\right): \delta 63.7$ (C-1), 79.9 (C-2), 137.9 (C-3), 129.8 (C-4), 145.5 (C-5), 109.1 (C-6), 81.5 (C-7), 76.2 (C-8), 81.9 (C-9), 73.8 (C-10), 106.4 (C-11), 149.5 (C-12), 61.2 (C-13), $102.7\left(\mathrm{C}-1^{\prime}\right), 74.0\left(\mathrm{C}-2^{\prime}\right), 77.1\left(\mathrm{C}-3^{\prime}\right), 70.2\left(\mathrm{C}-4^{\prime}\right), 76.8$ (C-5'), 61.0 (C-6'). HR-ESIMS: $m / z$ 403.1371 $[\mathrm{M}+\mathrm{Na}]^{+}$(calcd. for $\mathrm{C}_{19} \mathrm{H}_{24} \mathrm{O} 8 \mathrm{Na}, 403.1369$ ).

$2^{\prime}$-Butoxyethylconiferin (2): white amorphous powder; $[\alpha]_{\mathrm{D}}^{20}-27.22(c 0.06, \mathrm{MeOH}) ; \mathrm{UV}(\mathrm{MeOH}) \lambda_{\max }$ $(\log \varepsilon)$ 259, $202 \mathrm{~nm}$; IR (KBr) $v_{\max }$ 3438, 2922, 2853, 2026, 1725, 1710, 1630, 1512, 1462, 13834, $1127 \mathrm{~cm}^{-1}$; ${ }^{1} \mathrm{H}-\mathrm{NMR}\left(\mathrm{CD}_{3} \mathrm{OD}, 600 \mathrm{MHz}\right): \delta 7.06(1 \mathrm{H}, \mathrm{d}, J=8.4 \mathrm{~Hz}, \mathrm{H}-5), 7.03(1 \mathrm{H}, \mathrm{d}, J=1.8 \mathrm{~Hz}$, H-2), 6.90 (1H, dd, $J=8.4,1.8 \mathrm{~Hz}, \mathrm{H}-6), 6.54(1 \mathrm{H}, \mathrm{d}, J=15.6 \mathrm{~Hz}, \mathrm{H}-7), 6.20(1 \mathrm{H}, \mathrm{dd}, J=15.6,6.0 \mathrm{~Hz}$, H-8), 4.83 (1H, overlap, H-1"'), $4.12(2 \mathrm{H}, \mathrm{dd}, J=6.0,1.2 \mathrm{~Hz}, \mathrm{H}-9), 3.83\left(3 \mathrm{H}, \mathrm{s}, \mathrm{OCH}_{3}\right), 3.84(1 \mathrm{H}, \mathrm{m}$, H-6"' $\alpha$ ), 3.65 (1H, m, H-6"' $\beta), 3.58$ (2H, m, H-1'), 3.56 (2H, m, H-2'), $3.46\left(1 \mathrm{H}, \mathrm{m}, \mathrm{H}-4^{\prime \prime \prime}\right), 3.45(1 \mathrm{H}$, m, H-2"' ), 3.44 (2H, m, H-1"'), 3.36 (1H, m, H-3"'), 3.35 (1H, m, H-5"'), 1.52 (2H, m, H-2"), 1.34 (2H, m, H-3"), 0.88 (3H, t, $\left.J=7.2 \mathrm{~Hz}, \mathrm{H}-4^{\prime \prime}\right) .{ }^{13} \mathrm{C}-\mathrm{NMR}$ (CD $\left.3 \mathrm{OD}, 150 \mathrm{MHz}\right): \delta 133.4(\mathrm{C}-1), 111.4(\mathrm{C}-2)$, 150.9 (C-3), 147.8 (C-4), 117.9 (C-5), 120.9 (C-6), 133.3 (C-7), 125.9 (C-8), 72.7 (C-9), 70.5 (C-1'), 71.2 (C-2'), 72.1 (C-1"), 32.8 (C-2"), 20.3 (C-3"'), 14.2 (C-4"), 102.7 (C-1"'), 74.9 (C-2'"'), 78.2 $\left(\mathrm{C}-3^{\prime \prime \prime}\right), 71.3\left(\mathrm{C}-4^{\prime \prime \prime}\right), 77.8\left(\mathrm{C}-5^{\prime \prime \prime}\right), 62.5\left(\mathrm{C}-6^{\prime \prime \prime}\right), 56.7\left(\mathrm{OCH}_{3}\right)$. HR-ESIMS m/z 477.1917 [M + Cl] (calcd. for $\mathrm{C}_{22} \mathrm{H}_{34} \mathrm{O} 9 \mathrm{Cl}, 477.1891$ ).

8,3',4'-Trihydroxyflavone-7-O-(6"-O-p-coumaroyl)- $\beta$-D-glucopyranoside $\quad(3)$ : $\quad$ brownish-yellow amorphous powder; $[\alpha]_{\mathrm{D}}^{25}+7.22(c 0.03, \mathrm{MeOH})$; UV $(\mathrm{MeOH}) \lambda_{\max }(\log \varepsilon) 414,316 \mathrm{~nm}$; IR $(\mathrm{KBr}) v_{\max }$ 3405, 2923, 2853, 2026, 1688, 1649, 1603, 1513, 1443, 1383, 1278, 1168, 1129, $1076 \mathrm{~cm}^{-1}$; ${ }^{1} \mathrm{H}-\mathrm{NMR}$ (DMSO-d6, $600 \mathrm{MHz}): \delta 7.54\left(1 \mathrm{H}, \mathrm{d}, J=16.2 \mathrm{~Hz}, \mathrm{H}-7^{\prime \prime \prime}\right), 7.53\left(2 \mathrm{H}, \mathrm{d}, J=9.0 \mathrm{~Hz}, \mathrm{H}-2^{\prime \prime \prime}, 5^{\prime \prime \prime}\right), 7.44$ $\left(1 \mathrm{H}, \mathrm{d}, J=1.8 \mathrm{~Hz}, \mathrm{H}-2^{\prime}\right), 7.33\left(1 \mathrm{H}, \mathrm{dd}, J=7.8,1.8 \mathrm{~Hz}, \mathrm{H}-6^{\prime}\right), 7.11(1 \mathrm{H}, \mathrm{d}, J=8.4 \mathrm{~Hz}, \mathrm{H}-5), 7.04(1 \mathrm{H}$, $\mathrm{d}, J=8.4 \mathrm{~Hz}, \mathrm{H}-6), 6.85\left(1 \mathrm{H}, \mathrm{d}, J=7.8 \mathrm{~Hz}, \mathrm{H}-5^{\prime}\right), 6.79\left(2 \mathrm{H}, \mathrm{d}, J=9.0 \mathrm{~Hz}, \mathrm{H}-3^{\prime \prime \prime}, 6^{\prime \prime \prime}\right), 6.67$ (1H, s, H-3), 6.39 (1H, d, $\left.J=16.2 \mathrm{~Hz}, \mathrm{H}-8^{\prime \prime \prime}\right), 5.02\left(1 \mathrm{H}, \mathrm{d}, J=7.8 \mathrm{~Hz}, \mathrm{H}-1^{\prime \prime}\right), 4.44$ (1H, d, $\left.J=9.6 \mathrm{~Hz}, \mathrm{H}-6^{\prime \prime} \alpha\right)$, $4.21\left(1 \mathrm{H}, \mathrm{dd}, J=12.0,7.2 \mathrm{~Hz}, \mathrm{H}-6^{\prime \prime} \beta\right), 3.75\left(1 \mathrm{H}, \mathrm{m}, \mathrm{H}-5^{\prime \prime}\right), 3.43\left(1 \mathrm{H}, \mathrm{m}, \mathrm{H}-2^{\prime \prime}\right), 3.37$ (1H, m, H-3"), $3.27\left(1 \mathrm{H}, \mathrm{m}, \mathrm{H}-4^{\prime \prime}\right) .{ }^{13} \mathrm{C}-\mathrm{NMR}$ (DMSO-d6, $\left.150 \mathrm{MHz}\right): \delta 145.8(\mathrm{C}-2), 113.2(\mathrm{C}-3), 182.6(\mathrm{C}-4), 114.4$ (C-5), 112.0 (C-6), 152.3 (C-7), 132.8 (C-8), 117.4 (C-9), 154.4 (C-10), 123.6 (C-1'), 118.6 (C-2'), $\left.145.7\left(\mathrm{C}-3^{\prime}\right), 148.7\left(\mathrm{C}-4^{\prime}\right), 116.3\left(\mathrm{C}-5^{\prime}\right), 125.2\left(\mathrm{C}-6^{\prime}\right)\right), 101.4\left(\mathrm{C}-1^{\prime \prime}\right), 73.4\left(\mathrm{C}-2^{\prime \prime}\right), 75.8\left(\mathrm{C}-3^{\prime \prime}\right), 70.2$ (C-4"), 74.4 (C-5"), 63.5 (C-6"), 125.3 (C-1'"'), 130.6 (C-2'"'), 116.1 (C-3"'), 160.2 (C-4"'), 116.1 (C-5"'), 130.6 (C-6"'), 145.2 (C-7"'), 114.2 (C-8"'), 166.7 (C-9"'). HR-ESIMS: m/z 593.1316 $[\mathrm{M}-\mathrm{H}]^{-}$(calcd for $\left.\mathrm{C}_{30} \mathrm{H}_{25} \mathrm{O}_{13}, 593.1295\right)$.

\section{Conclusions}

A new polyacetylene glucoside $(3 E, 5 E, 11 E)$-tridecatriene-7,9-diyne-1,2,13-triol-2-O- $\beta$-Dglucopyranoside (1), a new phenylpropanoid glucoside, 2'-butoxyethylconiferin (2), and a new flavonoid glycoside, 8,3',4'-trihydroxyflavone-7-O-(6"-O-p-coumaroyl)- $\beta$-D-glucopyranoside (3), together with fifty-three known compounds 4-56 have been obtained from $B$. frondosa. Except compounds 20, 24, 26, 28, 33, 34, the other compounds were reported to isolate from $B$. frondosa for the first time. Compounds 1, 2, 3, 9, 15, 21, 24 and $\mathbf{5 1}$ showed significant activities in anti-inflammatory assays. And they exhibited good anti-inflammatory effects in a dose-dependent manner. The observed potential anti-inflammatory activity warrants further investigations. 


\section{Supplementary Materials}

Supplementary data (Figure S1, 1D-, 2D-NMR spectra and HR-ESIMS data of compounds $\mathbf{1}, \mathbf{2}$ and 3, HPLC profiles of compounds 1, 2, 3, 9, 15, 21, 24, 51 and EtOH extract of B. Frondosa, Table S1) associated with this article are available online.

Supplementary materials can be accessed at: http:/www.mdpi.com/1420-3049/20/10/18496/s1.

\section{Acknowledgments}

The work was financially supported by the National Natural Science Foundation of the People's Republic of China (Grant No. 81274032, 81325024, 81470173) and the Scientific Foundation of Shanghai (Grant No. 15401972200). The authors thank Jun Wang for anti-inflammatory assays.

\section{Author Contributions}

Zhijun $\mathrm{Wu}$ and Wansheng Chen designed the study. Jiamei Le and Zhijun $\mathrm{Wu}$ performed the experiment and wrote the manuscript. Jiamei Le and Wenquan Lu analyzed the data. Xiaojuan Xiong collected and identified the B. frondosa. All authors read and approved the final manuscript.

\section{Conflicts of Interest}

The authors declare no conflict of interest.

\section{References}

1. Rahman, A.; Bajpai, V.K.; Dung, N.T.; Kang, S.C. Antibacterial and antioxidant activities of the essential oil and methanol extracts of Bidens frondosa Linn. Int. J. Food Sci. Tech. 2011, 46, 1238-1244.

2. Venkateswarlu, S.; Panchagnula, G.K.; Subbaraju, G.V. Synthesis and antioxidative activity of 3',4',6,7-tetrahydroxyaurone, a metabolite of Bidens frondosa. Biosci. Biotech. Bioch. 2004, 68, 2183-2185.

3. Brandao, M.G.; Krettli, A.U.; Soares, L.S.; Nery, C.G.; Marinuzzi, H.C. Antimalarial activity of extracts and fractions from Bidens pilosa and other Bidens species (Asteraceae) correlated with the presence of acetylene and flavonoid compounds. J. Ethnopharmacol. 1997, 57, 131-138.

4. Zhao, J.; Wang, C.G. Antidiarrheal activity of Bidens frondosa. J. Nanjing Univ. TCM 1999, 15, 299-300.

5. Pagani, F.; Romussi, G. A new polyinic D-glucoside from Bidens frondosa flowers. Phytochemistry 1971, 10, 2233.

6. Pagani, F.; Romussi, G.; Bohhnann, F. Notiz uber die struktur des polyin-glucosids aus Bidens frondosa L. Chem. Ber. 1972, 10, 3126-3127.

7. Romussi, G.; Pagani, F. Constituents of Bidens frondosa L. Boll. Chim. Farm. 1970, 109, 467-475.

8. Karikome, H.; Ogawa, K.; Sashida, Y. New acylated glucosides of chalcone from the leaves of Bidens frondosa. Chem. Pharm. Bull. 1992, 40, 689-691. 
9. Le, J.M.; Wu, Z.J.; Xiong, X.J. Chemical constituents of Bidens frondosa L. Chin. Pharm. J. 2014, 49, 38-42.

10. Xi, F.M.; Li, C.T.; Han, J.; Yu, S.S.; Wu, Z.J.; Chen, W.S. Thiophenes, polyacetylenes and terpenes from the aerial parts of Eclipata prostrata. Bioorgan. Med. Chem. 2014, 22, 6515-6522.

11. He, J.; Shen, Y.; Jiang, J.S.; Yang, Y.N.; Feng, Z.M.; Zhang, P.C.; Yuan, S.P.; Hou, Q. New polyacetylene glucosides from the florets of Carthamus tinctorius and their weak anti-inflammatory activities. Carbohyd. Res. 2011, 346, 1903-1908.

12. Yue, Z.G.; Qin, H.; Li, Y.H.; Sun, Y.; Wang, Z.P.; Yang, T.H.; Liu, L.; Wang, M.C.; Feng, F.; Mei, Q.B. Chemical Constituents of the Root of Jasminum giraldii. Molecules 2013, 18, 4766-4775.

13. Yang, X.W.; Huang, M.Z.; Jin, Y.S.; Sun, L.N.; Song, Y.; Chen, H.S. Phenolics from Bidens bipinnata and their amylase inhibitory properties. Fitoterapia 2012, 83, 1169-1175.

14. Dai, Z.; Wang, G.L.; Lin, R.C. Chemical constituents of Balanophora simaoensis (III). Chin. Tradit. Herb Drugs 2006, 37, 1608-1610.

15. Shimoda, K.; Kondo, Y.; Nishida, T.; Hamada, H.; Nakajima, N.; Hamada, H. Biotransformation of thymol, carvacrol, and eugenol by cultured cells of Eucalyptus perriniana. Phytochemistry 2006, 67, 2256-2261.

16. Chen, Y.J.; Wang, H.T.; He, L.P.; Zhang, H.G.; Yin, J.L. Study on chemical constituents from bark of Fraxinus mandschurica Rupr. Chin. Pharm. J. 2009, 44, 1133-1136.

17. Ishikawa, T.; Fujimatu, E.; Kitajima, J. Water-soluble constituents of anise: New glucosides of anethole glycol and its related compounds. Chem. Pharm. Bull. 2002, 50, 1460-1466.

18. Liu, Y.B.; Qin, J.J.; Cheng, X.R.; Zhu, J.X.; Zhang, F.; Jin, H.Z.; Zhang, W.D. Three new neolignans and one new phenylpropanoid from the leaves and stems of Toona ciliata var. Pubescen. Helv. Chim. Acta 2011, 94, 1685-1691.

19. Zhao, L.; Li, L.Z.; Peng, Y.; Song, S.J. Isolation and identification of chemical constituents from seeds of Crataegus pinnatifida Bge. J. Shenyang Pharm. Univ. 2012, 29, 9-11.

20. Kikuzaki, H.; Hara, S.; Kawai, Y.; Nakatani, N. Antioxidative phenylpropanoids from berries of Pimenta dioica. Phytochemistry 1999, 52, 1307-1312.

21. Ouyang, M.A.; Chen, P.Q.; Wang, S.B. Water-soluble phenylpropanoid constituents from aerial roots of Ficus microcarpa. Nat. Prod. Res. 2007, 21, 769-774.

22. Wang, W.; Ding, Y.; Xing, D.M.; Wang, J.P.; Du, L.J. Studies on phenolic constituents from leaves of pineapple(Ananas comosus). Chin. J. Chin. Mater. Med. 2006, 31, 1242-1244.

23. Machida, K.; Nakano, Y.; Kikuchi, M. Phenolic glycosides from Viburnum dilatatum. Phytochemistry 1991, 30, 2013-2014.

24. Ma, H.Y.; Sun, Y.; Zhou, Y.Z.; Hong, M.; Pei, Y.H. Two new constituents from Artemisia capillaris Thunb. Molecules 2008, 13, 267-271.

25. Cao, X.; Li, C.J.; Yang, J.Z.; Wei, B.X.; Yuan, S.P.; Luo, Y.M.; Hou, Q.; Zhang, D.M. Four new neolignans from the leaves of Tripterygium wilfordii. Fitoterapia 2012, 83, 343-347.

26. Aboul-Ela, M.A.; El-Lakany, A.M.; Abdel-Kader, M.S.; Alqasoumi, S.I.; Shams-El-Din, S.M.; Hammoda, H.M. New quinic acid derivatives from hepatoprotective Inula crithmoides root extract. Helv. Chim. Acta. 2012, 95, 61-66.

27. Brandao, G.C.; Kroon, E.G.; Souza, D.E.; Souza Filho, J.D.; Oliveira, A.B. Chemistry and antiviral activity of Arrabidaea pulchra (Bignoniaceae). Molecules 2013, 18, 9919-9932. 
28. Jiang, Z.H.; Hirose, Y.; Iwata, H.; Sakamoto, S.; Tanaka, T.; Kouno, I. Caffeoyl, coumaroyl, galloyl, and hexahydroxydiphenoyl glucoses from Balanophora japonica. Chem. Pharm. Bull. 2001, 49, 887-892.

29. Nishibe, S.; Tamayama, Y.; Sasahara, M.; Andary, C. A phenylethanoid glycoside from Plantago asiatica. Phytochemistry 1995, 38, 741-743.

30. Silva, D.B.; Okano, L.T.; Lopes, N.P.; de Oliveira, D.C. Flavanone glycosides from Bidens gardneri Bak. (Asteraceae). Phytochemistry 2013, 96, 418-422.

31. Wang, Y.J.; Yang, X.W.; Guo, Q.S. Studies on chemical constituents in Huangjuhua (flowers Chrysanthemum morifolium). Chin. J. Chin. Mater. Med. 2008, 33, 526-530.

32. Xu, Y.; Wu, C.L.; Liu, Y.; Zhang, Z. Studies on chemical constituents of Saussurea tangutica Maxim. Chin. Tradit. Herb Drugs 2010, 41, 1957-1960.

33. Saracoglu, I.; Varel, M.; Harput, U.S.; Nagatsu, A. Acylated flavonoids and phenol glycosides from Veronica thymoides subsp. Pseudocinerea. Phytochemistry 2004, 65, 2379-2385.

34. Zhou, Z.H.; Yang, C.R. Chemical constituents of crude green tea, the material of Pu-er tea in Yunnan. Acta Bot. Yunnanica 2000, 22, 343-350.

35. Lu, Y.R.; Foo, L.Y. Flavonoid and phenolic glycosides from Salvia officinalis. Phytochemistry 2000, 55, 263-267.

36. Kraut, L.; Mues, R.; Sim-Sim, M. Acylated flavone and glycerol glucosides from two Frullania species. Phytochemistry 1993, 34, 211-218.

37. Jiang, R.Z.; Chen, Y.H.; Luo, H.M.; Xu, D.D.; Gao, Y.; Gao, Q.P. Isolation and structure identification of water soluble constituents from Ixeris Sonchifolia. Nat. Prod. Res. Dev. 2010, 22, $430-432$.

38. Zhao, A.H.; Zhao, Q.S.; Peng, L.Y.; Zhang, J.X.; Lin, Z.W.; Sun, H.D. A new chalcone glycoside from Bidens pilosa. Acta Bot. Yunnanica 2004, 26, 121-126.

39. Wang, J.; Wang, N.L.; Yao, X.S.; Kitanaka, S. Structures and anti-histamine activity of chalcones \& aurones compounds from Bidens parviflora Willd. Asia. J. Tradit. Med. 2007, 2, 23-29.

40. Cai, L.; Liu, C.S.; Fu, X.W.; Shen, X.J.; Yin, T.P.; Yang, Y.B.; Ding, Z.T. Two new glucosides from the pellicle of the walnut (Juglans regia). Nat. Prod. Bioprospect. 2012, 2, 150-153.

41. Jeong, D.M.; Jung, H.A.; Kang, H.S.; Choi, J.S. Peroxynitrite scavengers from Phellinus linteus. Nat. Prod. Sci. 2008, 14, 1-11.

42. Wu, Z.J.; Ou-Yang, M.A.; Yang, C.R. Polyphenolic constituents of Salvia sonchifolia. Acta Bot. Yunnanica 1999, 21, 393-398.

43. Huang, Y.; Chang, R.J.; Jin, H.Z.; Zhang, W.D. Phenolic constituents from Tsoongiodendron odorum Chun. Nat. Prod. Res. Dev. 2012, 24, 176-178.

44. Duan, J.; Li, W.; Hu, X.J.; Koike, K.; Fu, H.Z. Constituents of Silene rubicunda Franch. Chin. Tradit. Herb Drugs 2009, 40, 528-530.

45. Brown, G.D.; Liang, G.Y.; Sy, L.K. Terpenoids from the seeds of Artemisia annua. Phytochemistry 2003, 64, 303-323.

46. Zhang, X.; Lan, Z.; Dong, X.P.; Deng, Y.; Hu, X.M.; Peng, T.; Guo, P. Study on the active components of Nardostachys chinensis. Chin. Med. Mat. 2007, 30, 38-41. 
47. Guo, S.H.; Zhong, H.M.; Lin, W.H. Studies on the chemical constituents of the Marine Sponge (Xetospongia testudinaria) from the South China Sea. J. Qingdao Univ. Sci. Technol. 2007, 28, 502-504.

48. Li, X.; Song, S.J.; Piao, S.J.; Dong, T.; Lin, H.W. Studies on chemical constituents of marine sponge Aplysinopsis sp. Chin. J. Mar. Drugs 2009, 28, 21-25.

49. Shi, B.J.; Chou, G.X.; Wang, Z.T. Chemical constituents from Senecio nemorensis. J. Chin. Pharm. Univ. 2010, 41, 26-28.

50. Cheng, J.; Bai, Y.J.; Zhao, Y.Y.; Wang, B.; Cheng, T.M. Studies on the phenylpropanoids from Eucommia ulmoides. Chin. J. Chin. Mater. Med. 2002, 27, 38-40.

51. Ainiwaer, A.; Rena, K. Studies on the chemical constituents of seed from Nigella glandulifera. Chin. Med. Mat. 2007, 30, 1259-1261.

52. Boukamcha, H.; Jannet, H.B.; Bouazizi, Y.; Mighri, Z. Isolation and structure determination of a novel furanic ester from the aerial part of Prasium Majus. Nat. Prod. Res. 2003, 17, 63-66.

53. Ai, F.W.; Zhang, S.; Li, Y.F.; Ma, Y.L. Studies on the chemical constituents of Typhonium giganteum. Chin. Tradit. Herb Drugs 2010, 41, 201-203.

54. Kitajima, J.; Kimizuka, K.; Arai, M.; Tanaka, Y. Constituents of Ficus pumila leaves. Chem. Pharm. Bull. 1998, 46, 1647-1649.

55. Yu, Z.X.; Wang, G.L.; Bian-Ba, C.R.; Lin, R.C. Studies on chemical constituents in root of Phlomis medicinalis I. Chin. J. Chin. Mater. Med. 2006, 31, 656-658.

56. Chiang, Y.M.; Kuo, Y.H. Two novel $\alpha$-tocopheroids from the aerial roots of Ficus microcarpa. Tetrahedron. Lett. 2003, 44, 5125-5128.

57. Chang, M.H.; Wang, G.J.; Kuo, Y.H.; Lee, C.K. The low polar constituents from Bidens Pilosa L. var. Minor (Blume) Sherff. J. Chin. Chem. Soc. 2000, 47, 1131-1136.

58. Retief, L.; Mckenzie, J.M.; Koch, K.R. A novel approach to the rapid assignment of ${ }^{13}$ C-NMR spectra of major components of vegetable oils such as avocado, mango kernel and macadamia nut oils. Magn. Reson. Chem. 2009, 47, 771-781.

59. Mannina, L.; Luchinat, C.; Patumi, M.; Emanuele, M.C.; Rossi, E.; Segre, A. Concentration dependence of ${ }^{13} \mathrm{C}-\mathrm{NMR}$ spectra of triglycerides: Implications for the NMR analysis of olive oils. Magn. Reson. Chem. 2000, 38, 886-890.

60. Zeng, N.; Shen, Y.; Li, L.Z.; Jiao, W.H.; Gao, P.Y.; Song, S.J.; Chen, W.S.; Lin, H.W. Anti-inflammatory triterpenes from the leaves of Rosa laevigata. J. Nat. Prod. 2011, 74, 732-738.

61. Gao, H.; Zhao, F.; Chen, G.D.; Chen, S.D.; Yu, Y.; Yao, Z.H.; Wang, Z.; Li, J.; Yao, X.S. Bidesmoside triterpenoid glycosides from Stauntonia chinensis and relationship to anti-inflammation. Phytochemistry 2009, 70, 795-806.

Sample Availability: Samples of the compounds 1-56 are available from the authors.

(C) 2015 by the authors; licensee MDPI, Basel, Switzerland. This article is an open access article distributed under the terms and conditions of the Creative Commons Attribution license (http://creativecommons.org/licenses/by/4.0/). 